\title{
The Effect of Religious Identity toward Academic Performance: An Experimental Study
}

\author{
Shofwatun Amaliyah \\ Khairul Anwar \\ Fathul Lubabin Nuqul \\ Department of Psychology \\ State Islamic University of Maulana Malik Ibrahim Malang \\ Malang, Indonesia
}

\begin{abstract}
Indonesia is known as a multicultural country, including religious diversity. There were many internalhorizontal conflicts happened in Indonesia caused by this diversity. It becomes the most dominant factor that causes many recent conflicts. This study aimed to examine the effect of religious identity toward academic performance. This research was conducted using experiment method. As the sample, 34 students randomly selected from an Islamic University in Indonesia. The result of this study indicates that there is a significant effect of knowing teacher's religious identity toward student's academic performance $(F=90.477 ; p>0.000)$.
\end{abstract}

Keywords-Religious identity, academic performance, diversity

\section{INTRODUCTION}

It should be recognized that Indonesia is known as a multicultural country, including the religion and belief $[1,2$, 3]. A part of culture that plays a significant role in Indonesia is the religion [4]. Islam is the religion whose greatest number by approximately $87.2 \%$ of Indonesia's population. This situation makes Indonesia become the country with the largest Muslim population in the world. The other religions in Indonesia are Protestants (9.9\%), Hinduism (1.7\%), Buddhists (0.7\%), and Confucianism and others $(0.2 \%)$ [5].

Pluralism in Indonesia is regarded as an asset or privilege for Indonesia [6]. The positive potential of religion diversity is a source of values and local wisdom for the nation [3]. However, besides having positive potential, the diversity also potentially cause a crash, conflict, violence, and anarchism against other religions [7]. The number grievances of religious discrimination have been rising faster than gender or race claims [8]. There are many conflicts horizontal-internal in Indonesia and religion is the most dominant factor that cause the conflicts happened [6].

\section{A. Religious Identity}

Religious identity is a substantial dimension in the people's identity [9]. Because there is evidence that individuals tend to favor members of their group over outsiders [10]. People tend to feel comfortable and have more confidence if they on a common symbol (identity) [11]. This fact becomes evidence that religious identity makes a discrimination effect. Duriez and Hutsebaut indicated that there may be a positive relationship between religiosity and racism [12].

The emergence of a stereotype that group against another group from different religions cause religious conflicts [13]. Based on data from the Indonesia Human Rights Commission (Komnas HAM Indonesia) in 2010, there were 84 complaints about vandalism, harassment and 26 cases sealing of worship houses, 14 cases "cult" conflicts, and 7 cases internal conflicts, and other cases of discrimination. Even, in a period from 2007 to 2012 infraction in discrimination and religion freedom tend to become stronger and increase quantitatively [14].

\section{B. Academic Performance}

Academic performance is the result of the learning activity [15]. The student's performance (academic achievement) plays a significant role in producing the best quality graduates who will become a great leader and manpower for country thus responsible for the country's economic and social development [16]. The teacher is one of the factors that give success in the learning activity $[17,15]$. Teachers cannot be dissociated from the school, they teach and play the role in academic results of schools [18].

A number of studies have been done to identify causal factors of poor academic performance in the several institutions worldwide. Most of these studies focus on the three elements, parents (family causal factors), teachers (academic causal factors), and students (personal causal factors) [19]. According to Dunkin one aspect of teacher factors that affects student's performance is teacher performative experience, including gender, life-experiences and their social background [15].

\section{Present study}

Some researches has been done to explain about the gender, race and ethnicity. The previous studies about discrimination have examined such characteristics as age, gender, race and disability, and their relation to organizational behavioral outcomes [20]. The most Western literature on diversity workplace discuss about issues, such as gender, ethnicity, race, age, sexual orientation, and etc. [21] 
This study examines the effect of the teacher's religious identity towards academic performance of students. This topic was chosen because of religious issues (especially in Indonesia), has become a sensitive topic among religions. This case appropriate with Weiss that number of religious discrimination grievances has been rise faster than gender or race claims [8].

\section{METHOD}

\section{A. Sample}

The participants in this study are 34 Muslim students of psychology in the first grade and have not got any material about the psychological test; WAIS (Wechsler Adult Intelligence Scale).

\section{B. Material}

The instrument that used in this study is short questions to measure the academic performance of the subject. The number of question is ten questions about the psychological test; WAIS. Examples, "In what age the WAIS test is used?", "What is the aspect measured in the WAIS test?"

\section{Design}

This research uses an experimental design; sample was selected by random sampling. The subjects selected through social media (WhatsApp) by opening an invitation to join for the introduction of psychological test class. The chosen subjects have criteria as Muslim students in the first grade of University and never get any course about psychological tests before; WAIS. In this design, the sample randomly divided into two groups: group A and group B, consist 17 students each group.

The implementation of this experiment, researchers used a facilitator for giving the treatment. In the first session, subjects in group A were asked to enter the experimental room then given a pre-test in the format of questions about psychological tests WAIS. After pre-test facilitator enter the experimental room with a role as a lecturer, then introduced himself as a Muslim. The facilitator gives an explanation of the material WAIS test for 30 minutes to the group A. In the last session subjects in group A was given a post-test to measure the academic performance of the subjects after being given a treatment. The same thing is also done on the subject in group B. However, in this group is given the treatment through the same collaborator as a lecturer and introduced to identity as a Christian. Then in the last session, the group B was given a post-test to measure academic performance after being given the treatment.

\section{RESULTS}

This study indicates that the religious identity of the teacher affects students' academic performance. ( $\mathrm{F}=90.477$; $\mathrm{p}>0.000)$. The results show that the value of post-test groups with the same facilitator identity (Muslim: $\mathrm{M}=9.4706$ and SD
$=1.80685)$ compared with the group with a different facilitator identity (Christian: $\mathrm{M}=7.4118$ and $\mathrm{SD}=2.26547$ ).

To prove that the change was due to the treatment that was given and not because of differences in the subject, then performed an analysis of variance to pre-test below:

TABLE I. DESCRIPTIVE STATISTICS

\begin{tabular}{|l|c|c|c|}
\hline \multicolumn{1}{|c|}{$\begin{array}{c}\text { Academic } \\
\text { Performance }\end{array}$} & Mean & Std. Deviation & N \\
\hline $\begin{array}{l}\text { Pre-test group A } \\
\text { (Muslim) }\end{array}$ & 1.2353 & 1.34766 & 17 \\
\hline $\begin{array}{l}\text { Pre-test group B (Non } \\
\text { Muslim) }\end{array}$ & 1.2941 & 1.79460 & 17 \\
\hline
\end{tabular}

TABLE II. POST HOC ANALYSIS TEST

\begin{tabular}{|l|l|l|l|l|}
\hline $\begin{array}{c}\text { I } \\
\text { (Treatment) }\end{array}$ & $\begin{array}{c}\text { J } \\
\text { (Treatment) }\end{array}$ & MD (I-J) & $\begin{array}{c}\text { Std. } \\
\text { Error }\end{array}$ & Sig. \\
\hline $\begin{array}{l}\text { Pre-test } \\
\text { group A }\end{array}$ & $\begin{array}{l}\text { Pre-test } \\
\text { group B }\end{array}$ & -0.0588 & 0. & 0.926 \\
\hline $\begin{array}{l}\text { Post-test } \\
\text { group A }\end{array}$ & $\begin{array}{l}\text { Post-test } \\
\text { group B }\end{array}$ & 2.0588 & $\begin{array}{l}0 . \\
62858\end{array}$ & 0.002 \\
\hline
\end{tabular}

Table 2 above shows the results of a post hoc analysis test with a mean difference between pre-test of group A and pre-test of group B are -0.0588 and $p>0.926$. As for the value of post-test group A with post-test group B had a mean difference value 2.0588 and $p>0.002$. It can be concluded that the pre-test both group A and group B, did not have a significant difference, whereas in post-test group $A$ and group B there were significant differences ( $p>0.002)$.

\section{DISCUSSION}

A central goal in many disciplines is to understand how identity affects behavior [10]. Identity becomes critical in its role as the variable that affects the behavior, because according to Riis a person tends to feel comfortable and have more confidence to those who have a common symbol (identity) [11]. Recent developments in the field of social sciences, in general and sociology, in particular suggest a gradual tendency towards the revival of interest on the issue of religion and identity. There appears to be are relatively few papers that explore the topic of religion and spirituality as a conduit for identity recognition and formation [22].

The topic about religious identity frequently causes conflict and discrimination. Duriez and Hutsebaut indicated resources that there may be a positive relationship between religiosity and racism [12]. Indonesia has a high risk with gap caused by religious identity, considering that Indonesia is a country that has a diversity of religion and also a culture. This study was conducted to determine the effect of religious identity on the academic performance. Some studies show that religious identity has impacts on education [23]. 
Academic performance is an important aspect in the education field. It is because the academic performance is the result of a learning activities process that can be used as a measuring of the success. The success in learning is usually measured on a grade point average (GPA). The most of researchers around the word used to measure the GPA student performance [24]. High value of GPA indicates that the student has a good academic performance, while the low of GPA shows that students have poor academic performance.

The success in the learning process is determined by several factors. Teachers are one of the factors that affects the academic performance of students. Teachers cannot be dissociated from the school they teach and play the role in academic results of schools [18]. Teachers have a lot of influences in the class room [25]. Teachers have a significant effect on students' academic achievement. They play a crucial role in educational attainment because the teacher is ultimately responsible for translating policy into action and principles based on practice during interaction with students [26]. Several previous studies about teacher-factor explain that the influence of characteristics such as gender, educational qualifications and teaching experience on academic performance with various findings.

Akiri and Ugborugbo found that there was a significant relationship between teacher's gender and student's academic achievement [27]. Yala and Wanjohi and Adeyemi found that teacher's experience and educational qualifications were the prime predictors of a student's academic achievement [28, 29]. However, there is no study that specifically discusses the influence of teacher's religious and identity of the student's academic performance (achievement). Therefore, in this study the researchers want to know the effect of the religious identity factor on 34 students of Islamic University.

The result shows that the influence of teacher's religious identity toward the student's academic performance with the comparative results across the group $F=90.477(p=0.000)$. Data in the descriptive statistics indicate that the group A has a higher post-test with an average $\mathrm{M}=9.4706$ and $\mathrm{SD}=$ 1.80685 compared with group $\mathrm{B}$ which has an average posttest $\mathrm{M}=7.4118$ and $\mathrm{SD}=2.26547$. The results of a two-way analysis of variance with post hoc test mean difference values obtained post-test group A with group B equals 2. 0588 and the value of $p=0.002$. It shows that there are significant differences between the two.

The results of this study affirm earlier study that a teacher cannot be overlooked as one of the factors that influence students' academic performance. It may be additional factor that can be considered as teacher's aspects that affect the student's academic performance. The previous studies focus on factors such as different class schedules, class size, English text books, homework, the environment of the class, technology used in class and exams systems, extracurricular activities, family and work activities, financial, etc. [24]. This study may become contributing factors that influence on the student's academic performance.

\section{REFERENCES}

[1] Dadang, Sudiadi. 2009. Menuju Kehidupan Harmonis dalam Masyarakat yang Majemuk: Suatu Pandnagan tentang Pentingnya Pendekatan Multikultur dalam Pendidikan diIndonesia. Jurnal Kriminologi Indonesia. Vol. 5, No. 1.

[2] Titaley, John A. 2013. Religiousitas di Alenia Tiga: Pluralisme, Nasionalisme dan Transformasi Agamaagama. Salatiga: Satya Wacana University Press

[3] Hapsin, Abu, Komarudin \& Imroni, Arja M. 2014. Urgensi Regulasi Penyelesaian Konflik Umat Beragama: Perspektif Tokoh Lintas Agama. Walisongo. Vol. 22, No. 2

[4] Novita, Ananda. 2015. Addressing Religious Diversity in Education in Indonesia. Journal of Interdisciplinary Research in Education (JIRE).Vol. 5, pp. 109-119

[5] Badan Pusat Statistik Republik Indonesia. www.bps.go.id. Diakses pada 12-6-2016

[6] Pieter, Jeneman \& Titaley, John A. 2015. Hubungan antara Agama dan Kebhinekaan Indonesia (Studi Kasus terhadap Hubungan Warga Jemaat GPIB Tamansari Pospel kalimangli dengan Warga Muslim di Dusun Kalimangli). Jurnal Studi Agama dan Masyarakat.

[7] Attabik \& Sumiati. 2008. Pluralisme Agama: Studi tentang Kearifan Lokal di Desa Karangbenda, Kecamatan Adipala, Kabupaten Cilacap. Jurnal Penelitian Agama (JPA). Vol. 9, No. 2

[8] Weiss, D.C. (2008, Oct. 16). Meatpacker Prayer Dispute Among Rising Complaints of Religious Bias. American Bar Association Journal

[9] Judith N. Martin, Thomas K. Nakayama. 2009. Intercultural Communication in Contexts. McGraw Hill. pp. 180-192. ISBN 978-0-07-338512-9

[10] Gautam, Gupta. 2013. Religion, Minority Status and Trust: Evidence from a Field Experiment. Department of Economics ISSN 1441-5429

[11] Riis. 2011, Rejection of Religious Pluralism- The Danish Case. Nordic Journal of Religion and Society 24 (1): 1936

[12] Duriez, B \& Hutsebaut, D. 2000. The Relation between Religion and Racism: The Role of post-Critical Beliefs. Mental Health, Religion \& Culture. 3 (1)

[13] Yunus, M. Firdaus. 2014. Konflik Agama di Indonesia Problem dan Solusi Pemecahannya. Jurnal Substantia. Vol. 16, No. 2

[14] Based on Data KOMNAS HAM Indonesia, 2010

[15] Riyani, Yani. 2012. Faktor-faktor yang Mempengaruhi Prestasi Belajar Mahasiswa (Studi pada Mahasiswa Jurusan Akuntansi Politeknik Negeri Pontianak). Jurnal EKSOS. Vol. 8, No. 1

[16] Ali, Norhidayah, Jusoff, Kamaruzaman, Ali, Syukriah, Mokhtar, Najah and Samalt, AzniSyafena Andin. 2009. The Factors Influencing Students' Performannce at Universiti Teknologi MARA Kedah, Malaysia. Canadian Research \& Development Center of Sciences and Cultures: Vol. 3, No. 4

[17] Linda, Setiawati. Faktor-faktor yang mempengaruhi prestasi belajar praktik kejuruan siswa SMK program studi keahlian teknik komputer dan informatika. Jurnal Pendidikan Vokasi. 3-2-5

[18] Kimani, Gerald N, Kara, Augustine M, \& Njagi, Lucy W. 2013. Teacher Factors Influencing Student's Academic Achievement in Secondary Schools in Nyandarua Country, Kenya. International Journal of Education and Research. Vol. 1, No. 3

[19] Mlambo, Victor. 2011. An Analysis of some factors affecting student academic performance in an introductory 
biochemistry course at the university of the West Indies. Caribbean Teaching Scholar. Vol. 1, No. 2

[20] See on Channar, Z. Abbassi, Z and Ujan, I. A. 2011. Gender discrimination in workforce and its impact on the employees. Pak. J. Commer. Soc. Sci. 5 (1), 177-191

[21] Messara, L. C. 2014. Religious Diversity at Work: The Perceptual Effect of Religious Discrimination on Employee Engagement and Commitment. Contemporary Management Research. Vol. 1, No.

[22] Oppong, Steward H. 2013. Religion and Identity. International Journal of Contemporary Reseacrh. Vol. 3, No. 6

[23] Chaudhary, Latika and Rubin, Jared. 2015. Religious Identity and Provision of Public Goods: Evidence from the Indian Princely State. Journal of Economic Literature (JEL)

[24] Mushtaq, Irfan \& Khan, Shabana Nawaz. 2012. Factors Affecting Student's Academic Performance. Global Journal of Management and business Research. Vol. 12,
Issue 9

[25] Kosgei, Anita, Jairo K. M, Odera O, Mary E. A. 2013. Influence of teacher characteristics on student's academic achievement among secondary schools. Journal of Education and Practice. Vol. 4, No. 3

[26] Worthington, A. 2001. An Empirical Survey of Frontier Efficiency Measurement Techniques in Education. Education Economics, 9(3): 245-268

[27] Akiri, A. A \& Ugborugbo, N. M. 2008. An Examination of Genders Influence on Teachers Productivity in Secondary Schools. J. Soc. Sci, 17 (3): 185-191

[28] Yala, P. O. \& Wanjohi, W. C. 2011. Performance Determinants of KCSE in Mathematics in Secondary Schools in Nyamira Division, Kenya. Asian Social Science. 7(2): 107-112

[29] Adeyemi, B. 2010. Teacher Related Factors as Correlates of Pupils Achievement in Social Studies in South West Nigeria. Electronic Journal of Research in Educational Psychology. 8(1): 313-332 